\title{
SPECIFIC TYPES OF RELATED PARTIES AND TRANSACTIONS WITH THEM IN INTERNATIONAL STANDARD ON AUDITING 550: IMPACT ON THE ASSESSMENT OF RISK OF MATERIAL MISSTATEMENT AND ESTABLISHING THE ENTITY'S ACCOUNTING POLICY
}

\author{
Nataliia Shalimova', Yana Klymenko²
}

\begin{abstract}
The purpose of the study is to identify the impact of specific types of related parties, which are allocated in International Standards on Auditing 550 "Related Parties", not only on the organization of the audit of financial statements in the context of assessing the risk of material misstatement, but also on the organization of accounting in enterprises. To achieve the goal set in the work, a complex of general scientific methods (analysis, synthesis, induction, deduction, abstraction) and methodical techniques (systematization, generalization, review, comparison) based on the provisions of International Standards of Auditing was used. In the study of the essence of related parties transactions and elaboration their classification method of system analysis, logical method, and method of modeling were used. There are three major tasks within the overall responsibility of the auditor while fulfilling such engagement as audit of the financial statements have been determined. It is substantiated that two different phrases ("has a responsibility to perform audit procedures" and "needs to obtain an understanding") which are used in International Standards on Auditing 550 "Related Parties" requires a separate approach to formation a set of optimal audit procedures. Specific types of related parties based on the International Standards 550 "Related Services" that should be considered when performing audit of financial statements has been identified. Classification of related parties transactions according to their riskiness and connection with the normal course of business into four different types has been elaborated. Two groups of inquiries concerning related parties transactions have been analyzed. It has been proved that making inquiries the auditor should provide as much information as possible in order to avoid misunderstandings, which may lead to difficulties in forming an opinion. It is noted that determining the characteristics of the dominant influence and significant transactions will allow effective communication and cooperation between auditors, management staff and those responsible for governance in formation inquires and answers for them. Using proposed classification in the process of audit of financial statements and in developing regulatory documents for accounting at the entity will allow appropriate assessing of risk of material misstatement and increasing the effectiveness of internal control at the entity. It has been substantiated that the objectives of accounting policy not only in terms of meeting the interests of the company as an entity that prepares financial statements and interacts with related parties, but also in terms of meeting the interests of the entity as a responsible party, interacting with the auditor, that seeks to establish an internal control system that will ensure reducing its own risks.
\end{abstract}

Key words: audit engagements, audit of financial statements, related parties, related parties transactions, risk of material misstatement, significant transactions, audit evidence, inquiry, accounting policy, internal control.

JEL Classification: M40, M42

\footnotetext{
Corresponding author:

${ }^{1}$ Central Ukrainian National Technical University, Ukraine.

E-mail: nataliia.shalimova@gmail.com

ORCID: https://orcid.org/0000-0001-7564-4343

${ }^{2}$ Central Ukrainian National Technical University, Ukraine.

E-mail: Yana_Rud@bigmir.net

ORCID: https://orcid.org/0000-0002-3233-6938
} 


\section{Introduction}

The integration of global processes in symbiosis with the globalization of markets has a significant impact on the national economy, which leads to the complication of economic and financial relations. First, the number of corporate associations that have branches, subsidiaries, separate divisions in different countries is increasing, the number of business structures with foreign capital is growing; secondly, contracts of various nature have begun to be concluded, which are connected not only with purchase and sale operations, but also with more complex and specific operations. It should be noted that so-called intergroup operations, operations and relations between related parties are of particular interest, and the terms "affiliated companies", "related parties", "controlled transactions", "final beneficiaries" have now penetrated into almost all sectors of the economy, management, law. These transactions significantly affect the formation of financial statements, and therefore the specifics of this activities allows to distinguish audit services in the sphere of related parties transactions as a separate area, the potential of which is constantly growing.

Despite the existence of a separate International Standard on Auditing 550 "Related Parties" (ISA 550 "Related Parties"), the development of organizational and methodological principles for auditing of related parties in order to meet the information needs of different users remains one of the insufficiently studied spheres of audit theory and practice.

\section{Literature review and purpose of the study}

Related party transactions are important primarily for the accounting and preparation of financial statements, and they are investigated in this context to a greater extent. Issues of audit of related parties transactions are considered superficially and only in some aspects, namely: while studying the scope of audit procedures for small businesses (Tsarenko, Karmazina, 2016), the process of documenting the audit procedures (Antoniuk, 2018), the organization of communication with management staff or those charged with government (Riadska, 2015). Among the latest dissertation research it is necessary to distinguish the work of V. Fesenko (Fesenko, 2019), which is devoted to the methodology of audit and analysis of foreign economic activity of related enterprises. Specific issues of organizational and methodological aspects of the audit of related parties transactions are considered in a limited number of publications (Honcharova, 2020; Novichenko, 2020). It should be noted that Audit Chamber of Ukraine has published generalized reports on the analysis of typical errors that were identified during external inspections of the system of quality control (ACU, 2019), within which attention is focused on the problems of compliance with the requirements of ISA 550 in the process of audit of financial statements.

It should be noted that foreign scholars are much more deeply researching the specific issues of audit of related parties transactions. In this context, it is worth noting the review of auditing literature about related-party transactions, presented by M. El-Helaly (ElHelaly, 2018). Deficiencies in Auditing RelatedParty Transactions has been analyzed (Louwers, Henry, Reed, Gordon, 2008), role of related party transactions in fraudulent financial reporting has been substantiated (Henry, Gordon, Reed, Louwers, 2012). The role of audit quality in the interplay between related party transactions and earnings management has been investigated (ElHelaly, Georgiou, Lowe, 2018). The influence of auditing related party transactions on the audit opinion and judgement has been deeply analyzed (Fang, Lobo, Zhang, Zhao, 2017; Mustikarini, Khansa, 2017; Yang, Ruan, Tang, 2020).

The presented analysis shows the importance of research of the outlined problems and their significance for the formation of an effective system of accounting and auditing. The purpose of this study is to identify the impact of specific types of related parties, which are allocated in ISA 550 "Related Parties", not only on the organization of the audit of financial statements in the context of assessing the risk of material misstatement, but also on the organization of accounting in enterprises. Establishing this relationship based on a meaningful and systematic analysis of the provisions of International Standards on Auditing is necessary in terms of identifying ways to reduce the components of audit risk and increase the effectiveness of communication between the auditor and management.

\section{Auditor's area of responsibility in accordance with ISA 550}

ISA 550 "Related Parties" requires that auditors need to examine related parties and their 
transactions, whether or not there are specific requirements for the accounting and disclosure of related party relationships, transactions and balances in the financial reporting framework. There are three major tasks within the overall responsibility of the auditor while fulfilling such engagement as audit of the financial statements (ISA 550, paragraphs 3-6):

1) the auditor has a responsibility to perform audit procedures to identify, assess and respond to the risks of material misstatement arising from the entity's failure to appropriately account for or disclose related party relationships, transactions or balances in accordance with the requirements of the framework;

2) the auditor needs to obtain an understanding of the entity's related party relationships and transactions sufficient to be able to conclude whether the financial statements, insofar as they are affected by those relationships and transactions: achieve fair presentation (for fair presentation frameworks); or are not misleading (for compliance frameworks);

3 ) the auditor needs to obtain an understanding of the entity's related party relationships and transactions sufficient to be able to evaluate whether one or more fraud risk factors are present as required by ISA 240 "The Auditor's Responsibility to Consider Fraud in an Audit of Financial Statements" because fraud may be more easily committed through related parties.

Thus, ISA uses two basic phrases (actually guidelines): "has a responsibility to perform audit procedures" and "needs to obtain an understanding". The first phrase is used in the context of an audit of financial statements, in the preparation of which the disclosure of information about related parties is mandatory and financial reporting frameworks establish specific accounting and disclosure requirements for related party relationships, transactions and balances to enable users of the financial statements to understand their nature and actual or potential effects on the financial statements. The second phrase is used in the context of an audit of financial statements, when such disclosure is not required (requirements are minimal or non-existent in the financial reporting framework). The use of such different phrases creates difficulties in forming a set of optimal audit procedures.

\section{Specific types of related parties and transactions with them in the context of an audit of financial statements}

International Standards on Auditing provide not only a description of tasks and procedures, but also special types of related parties and transactions with them.

It is noted that related party transactions (at least many of them) are in the normal course of business (ISA 550, paragraph 2). Certain provisions of ISA 550 "Related Parties" pay particular attention to the relationship between related party transactions and the normal course of business, in particular in the context of examining the process of authorizing and approving them (paragraph 14). Therefore, transactions with related parties may be carried out in the ordinary course of business, or may go beyond the normal course of business of the entity. Therefore, the first feature of the classification of related parties and transactions with them is the connection of transactions with the normal course of business.

Also, ISA 550 "Related Parties" draws attention to the fact that transactions with related parties are not necessarily of high risk and not necessarily give rise to a higher risk of material misstatement of the financial statements than in similar transactions with unrelated parties. Therefore, for the purposes of audit of financial statements, the second classification feature of related party transactions can be distinguished: the probability of a higher risk of material misstatement of the financial statements.

The combination of the mentioned above classification features allows to distinguish four types of transactions with related parties, namely:

Type I - transactions that occur in the framework of normal course of business and are characterized by high risk;

Type II - transactions that occur in the framework of normal course of business and are not characterized by high risk;

Type III - transactions that occur outside the normal course of business and which are characterized by high risk;

Type IV - transactions that occur outside the normal course of business and which are not characterized by high risk (Table 1 ).

The auditor should identify and assess the risks of material misstatement of the related party relationship and transactions and determine whether any of those risks are significant risks. 
Significant transactions with related parties relate to conditions and events that may indicate risks of material misstatement (IAS 315 (Revised) "Identifying and assessing the risk of material misstatement", appendix 2). But ISA 550 interprets this provision more rigidly, as it emphasizes that in any case, significant related party transactions that go beyond the normal course of business of the entity are of high risk and give rise to significant risks (paragraph 18). Complementing the previous classification with significant transactions, it should be noted that this category are of part of type III transactions and not of high but of significant risk. As for significant related party transactions in the ordinary course of business, they may be part of both type I and type II transactions, depending on other factors.

However, it should be noted that there is no clear definition of the category of "significant transactions", which complicates the work of auditors and requires in each case to establish quantitative and qualitative characteristics of significant transactions.

Table 1

Classification of transactions with related parties according to the connection with the normal course of business and the level of risk of material misstatement

\begin{tabular}{|c|c|c|}
\hline & Transactions that carry higher risk & Transactions that carry no higher risk \\
\hline 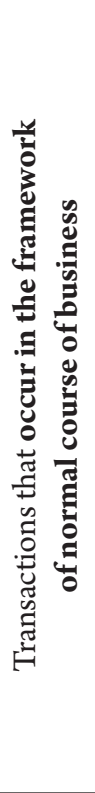 & $\begin{array}{l}\text { Type I } \\
\text { - purchase or sale of products (goods, services), } \\
\text { provided under the conditions that the transaction price } \\
\text { is set above the level of normal prices; } \\
\text { - purchase or sale of other assets, provided under the } \\
\text { conditions that the transaction price is set above the level } \\
\text { of normal prices; } \\
\text { - futures transactions; } \\
\text { - lease transactions, provided under the conditions that } \\
\text { the price set by the terms of the contract is higher than } \\
\text { market prices; } \\
\text { - provision and receipt of guarantees and pledges, if the } \\
\text { contract price is set above the market price and the terms } \\
\text { of the contract are non-typical; } \\
\text { - financial transactions in which the value of assets does } \\
\text { not correspond to the level of market prices; } \\
\text { - transactions with senior management and their close } \\
\text { family members of significant characteristics. }\end{array}$ & $\begin{array}{l}\text { Type II } \\
\text { - purchase or sale of finished products (goods, works, } \\
\text { services), provided under the conditions that the } \\
\text { transaction price is set not higher than normal prices; } \\
\text { - purchase or sale of other assets, provided under the } \\
\text { conditions that the transaction price is not higher than } \\
\text { normal prices; } \\
\text { - operations under agency agreements; } \\
\text { - operations under license agreements; } \\
\text { - lease transactions, provided under the conditions that } \\
\text { the price set by the terms of the contract corresponds to } \\
\text { the level of market prices; } \\
\text { - provision and receipt of guarantees and pledges, if the } \\
\text { price and terms of the contract fully comply with market } \\
\text { price indicators and are not non-typical; } \\
\text { - financial transactions in which the value of assets } \\
\text { corresponds to the level of market prices; } \\
\text { - standard operations with senior management and their } \\
\text { close family members. }\end{array}$ \\
\hline 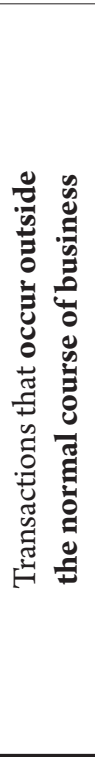 & $\begin{array}{l}\text { Type III } \\
\text { - sales transactions with unusually large discounts or the } \\
\text { possibility of returning goods; } \\
\text { - complex equity transactions (corporate restructuring, } \\
\text { acquisitions, etc.); } \\
\text { - transactions with offshore entities in jurisdictions with } \\
\text { weak corporate law; } \\
\text { - lease of premises or provision of management } \\
\text { services by an economic entity to another party without } \\
\text { monetary remuneration; } \\
\text { - transactions with repurchase agreements, such as sale } \\
\text { with a repurchase obligation; } \\
\text { - transactions under contracts, the terms of which } \\
\text { changed before the expiration of their validity; } \\
\text { - operations performed under conditions of significant } \\
\text { changes in the logistics chain; } \\
\text { - operations related to the sale of business segments of } \\
\text { the entity. }\end{array}$ & $\begin{array}{l}\text { Type IV } \\
\text { - operations related to the sale of new types of finished } \\
\text { products (goods, services); } \\
\text { - non-significant one-time payments to senior } \\
\text { management (payments upon dismissal and at the end of } \\
\text { employment, payments on loans, etc.); } \\
\text { - changes in the composition of the main management } \\
\text { staff; } \\
\text { - transactions under contracts, the terms of which } \\
\text { changed before the expiration of their validity, the value } \\
\text { of which is recognized as insignificant; } \\
\text { - minor operations performed in the event of changes in } \\
\text { the logistics chain; } \\
\text { - realization of a small part of shares and corporate rights } \\
\text { that will not lead to a change in the structure of direct or } \\
\text { indirect participation in determining legal entities and } \\
\text { individuals as related. }\end{array}$ \\
\hline
\end{tabular}

Source: compiled by the authors 
Traditional factors in the identification of related parties are the presence of "significant influence" or "control", these factors are also used in ISAs. Significant influence is interpreted as the power to participate in the financial and operating policy decisions of an entity, but is not control over those policies. Control is defined as the power to govern the financial and operating policies of an entity so as to obtain benefits from its activities. At the same time, ISA 550 emphasizes the possibility of existing of exert dominant influence over the entity or its management (paragraph A6). It is recommended to use dominant influence assessment to identify and assess the risks of material misstatement due to fraud. However, the lack of a clear interpretation of the dominant influence makes it difficult to identify and evaluate it to detect fraud.

\section{Formation of the inquiries about related parties transactions}

ISA 500 "Audit Evidence" identifies audit procedures such as inquiries, which are defined as the process of seeking information of knowledgeable persons, both financial and nonfinancial, within the entity or outside the entity (paragraph A22), and external confirmations as a special type request, which means the process of obtaining a direct written response from a third party (confirming party) in paper, electronic or other form (paragraph A18).

ISA 550 focuses on such type of audit evidence as inquiries, which can be presented in the following groups:

Group I. Inquiries at the beginning of the audit of financial statements; inquiries are mandatory.

Subgroup 1.1. Inquiries "Nature of Related Parties" includes the need to obtain information about:

- identification of the entity's related parties, including changes from the prior period;

- the nature of the relationships between the entity and these related parties;

- entering by the entity into any transactions with these related parties during the period and, if so, the type and purpose of the transactions.

Subgroup 1.2. Inquiries"Understanding of control measures (if any) established by management" implies the need to obtain information about the procedure (conditions, mechanisms) that are used in order to:

- identify, account for, and disclose related party relationships and transactions in accordance with the applicable financial reporting framework;
- authorize and approve significant transactions and arrangements with related parties;

- authorize and approve significant transactions and arrangements outside the normal course of business.

It should be noted that ISA 550 emphasizes that such inquiries are also useful in recurring audit engagements, as inquiries provides a basis for comparing the information supplied by management with the auditor's record of related parties noted in previous audits.

Group II. Inquiries in the process of auditing financial statements; the inquiry is made- if the auditor in performing audit procedures reveals significant transactions that go beyond the normal course of business. In this case, the auditor should ask management about:

- the nature of these transactions, involving obtaining an understanding of the business rationale of the transactions, and the terms and conditions under which these have been entered into;

- the possible involvement of related parties, directly influencing the transaction through being a party to the transaction or indirectly influencing it through an intermediary.

Assessing the content of the inquiries to be addressed by the auditor, one important problem can be distinguished - the need to clearly identify significant transactions about which the company must provide information. In this context, it should be noted that when conducting transactions with related parties and their audit, information inconsistency or information asymmetry has a significant impact. The reasons of such situation can be various:

- firstly, management may not understand the nature of certain transactions with related parties; - secondly, management may not be aware of the existence of all relationships and transactions with related parties;

- thirdly, in the interpretation by management and the auditor of such categories as "significant transactions", "normal course of business", "dominant influence" can be presented significant variability.

In making inquiries accordingly, the auditor should provide as much information as possible in order to avoid misunderstandings, which may lead to difficulties in forming an opinion.

In addition, ISA 315 (Revised) "Identifying and assessing the risk of material misstatement through 
understanding the entity and its environment" and ISA 260 (Revised) "Communication with those charged with governance" identify the interaction of those charged with governance and external auditors as an element of the entity's control environment (ISA 315, paragraph A78; ISA 260, paragraph A52). Therefore, insufficient and inadequate two-way communication of information may indicate an unsatisfactory control environment, affect the auditor's assessment of the risks of material misstatement and, ultimately, his or her opinion. If the audit of the financial statements reveals that the twoway communication of information between the auditor and those charged with governance is insufficient and cannot be resolved, the auditor should modify the auditor's opinion based on the scope limitation or even withdrawing from the engagement (ISA 260, paragraph A53).

\section{Improving the effectiveness of internal control of related parties transactions and communication with auditors}

ISA 550 "Related Parties" emphasizes that an entity's information systems should record, process, and aggregate related party relationships and transactions to enable the entity to meet the accounting and disclosure requirements of the framework (paragraph A11). But it is critical that the capabilities of information systems are used not only to generate reports in accordance with the requirements of regulations, but also to reduce the risk in the entities activities.

Identification and specification of specific types of related parties is important because it allows to understand key aspects of the audit, but on the other hand, it allows to determine the guidelines of the internal control system of entities for which transactions and relationships with related parties are critical and significant.
Accordingly, when forming the accounting policy of the enterprise, it is advisable to provide for the classification of related parties in accordance with such factors as: riskiness of related parties transactions, connection with the normal course of business, presence of a dominant influence. It is also necessary to specify the definitions of "significant transactions" and "dominant influence" by setting quantitative and qualitative limits, because this is important for internal control, as well as for the formation of responses to inquiries. This approach allows to consider the objectives of accounting policy not only in terms of meeting the interests of the company as an entity that prepares financial statements and interacts with related parties, but also in terms of meeting the interests of the company as a responsible party interacting with the auditor, and an entity that seeks to establish an internal control system that reduces its own risks.

\section{Conclusions}

To regulate the procedure for assessing related parties transactions, ISA 550 "Related parties" identifies specific types of related parties that should be considered not only when performing audit of financial statements, but it is advisable to use by companies in developing regulatory documents for accounting at the enterprise.

Classification of types of transactions according to the riskiness of transactions with them and connection with the normal course of business, determining the characteristics of the dominant influence and significant transactions will allow to assess audit risk and determining the benchmarks for internal control in the enterprise. However, it should be noted that the understanding of the dominant influence and significant operations of the entity and the auditor may differ, which requires consistent communication in the formation of requests and processing of their results.

\section{References:}

Antoniuk, O.R. (2018). Vektory rozvytku system kontroliu yakosti nadannia audytorskykh posluh v Ukraini [Vectors of development of quality control systems for audit services in Ukraine]. Hlobalni ta natsionalni problemy ekonomiky [Global and national economic problems] (electronic journal), no. 21. Available at: http://global-national.in.ua/issue-21-2018/29-vipusk-21-lyutij-2018-r/3833-antonyuk-or-vektori-rozvitku-sistemi-kontrolyu-yakosti-nadannya-auditorskikh-poslug-v-ukrajini

Audytorska palata Ukrainy (2019). Analiz typovykh pomylok, yaki buly vyiavleni pid chas zovnishnikh perevirok systemy kontroliu yakosti, provedenykh vidpovidno do vymoh Polozhennia pro zovnishni perevirky systemy kontroliu yakosti audytorskykh posluh, zatverdzhenoho rishenniam Audytorskoi palaty Ukrainy vid 30.10.2014 № 302/9 (zi zminamy) do nabrannia chynnosti Zakonu Ukrainy «Pro audyt finansovoi zvitnosti ta audytorsku diialnist» [Analysis of typical errors that were identified during external inspections of the quality control system, conducted in accordance with the requirements of the 
Regulation on external inspections of the quality control system of audit services, approved by the Audit Chamber of Ukraine dated 30.10.2014 № 302/9 (as amended) before the Law Of Ukraine "On audit of financial statements and audit activities"]. Available at: https://cutt.ly/MkiW5JB

El-Helaly, Moataz (2018). Related-Party Transactions: A Review of the Regulation, Governance, and Auditing Literature (August 15, 2018). Managerial Auditing Journal, Forthcoming. doi: 10.1108/MAJ07-2017-1602

El-Helaly, Moataz, Georgiou, Ifigenia, \& Lowe, Alan D. (2018). The Interplay between Related Party Transactions and Earnings Management: The role of Audit Quality. Journal of International Accounting, Auditing and Taxation, vol. 32, pp. 47-60.

Fang, Junxiong, Lobo, Gerald, Zhang, Yinqi, \& Zhao, Yuping (2017). Auditing Related Party Transactions: Evidence from Audit Opinions and Restatements. Auditing. A Journal of Practice \& Theory, April 2017, no. 37(2), pp. 73-106. doi: 10.2308/ajpt-51768

Fesenko, V. V. (2019). Metodolohiia audytu ta analizu zovnishnoekonomichnoi diialnosti poviazanykh pidpryiemstv [Methodology of audit and analysis of foreign economic activity of related companies] (PhD Thesis), Dnipro: Ternopil. nats. ekon. un-t.

Henry, Elaine, Gordon, Elizabeth A., Reed, Brad J., \& Louwers, Timothy J. (2012). The Role of Related Party Transactions in Fraudulent Financial Reporting. Journal of Forensic \& Investigative Accounting, vol. 4 , issue 1.

Honcharova, V. H. (2020). Orhanizatsiino-metodychni pidkhody do audytu operatsii z poviazanymy osobamy [Organizational and methodological approaches to the audit of transactions with related parties]. Ahrosvit [Agro-world], no. 13-14, pp. 54-60.

International Federation of Accountants (IFAC/IAASB) (2016-2017). Supplement to the Handbook of International Quality Control, Auditing, Review, Other Assurance, and Related Services Pronouncements, vol. I, 2016-2017 Edition. Available at: https://www.ifac.org/publications-resources/2016-2017handbook-international-quality-control-auditing-review-other

Louwers, Timothy J., Henry, Elaine, Reed, Brad J. \& Gordon, Elizabeth A. (2008). Deficiencies in Auditing Related-Party Transactions: Insights from AAERs. Current Issues in Auditing American Accounting Association, vol. 2, issue 2, pp. A10-A16.

Mustikarini, Arizona, \& Khansa, Nadia Destianne (2017). Do Related Party Transactions Matter to Auditors? Evidence from Audit Opinion. Proceedings of the 18th Asian Academic Accounting Association (FourA) Annual Conference (Indonesia, Bali, November 22-23, 2017).

Novichenko, L. S. (2020). Audyt operatsii iz poviazanymy storonamy [Audit of related party transactions]. Proceedings of the Stratehiia rozvytku Ukrainy: VII Mizhnarodna naukovo-praktychna konferentsiia (Ukraine, Kyiv, 2020). Kyiv: Informatsiino-analitychne ahentstvo, pp. 184-186.

Riadska, V. V. (2015). Audyt u rozvytku pidpryiemnytskoi diialnosti v Ukraini [Audit in the development of entrepreneurial activity in Ukraine] (PhD Thesis), Kyiv: Kyiv. nats. ekon. un-t im. V. Hetmana.

Tsarenko, O. V., \& Karmazina, N. V. Umovy zabezpechennia kerovanoho vplyvu mizhnarodnykh standartiv audytu na efektyvnist diialnosti maloho biznesu v rehionakh Ukrainy [Conditions for ensuring the managed impact of international auditing standards on the efficiency of small business in the regions of Ukraine]. Scientific Bulletin of Polissia, vol. 2, pp. 103-107.

Yang, L., Ruan, L., \& Tang, F. (2020). "The impact of disclosure level and client incentive on auditors' judgments of related party transactions". International Journal of Accounting \& Information Management, vol. 28, no. 4, pp. 717-737. doi: 10.1108/IJAIM-02-2020-0016 